\title{
(Review) \\ Teknik Pengendalian Nematoda Puru Akar (Meloidogyne spp.) Ramah Lingkungan
}

\author{
Dina Istiqomah ${ }^{1}$, Ankardiansyah Pandu Pradana $^{2}$ \\ 1) Mahasiswa Program Studi Fitopatologi, Jurusan Ilmu Hama dan Penyakit Tumbuhan, \\ Universitas Gadjah Mada, Email: dinasti.1990@yahoo.co.id \\ 2) Mahasiswa Program Studi Fitopatologi, Departemen Proteksi Tanaman, Institut Pertanian \\ Bogor, Email: pandupradana.id@gmail.com
}

\begin{abstract}
ABSTRAK
Nematoda puru akar (NPA) Meloidogyne spp. merupakan salah satu patogen penting pada berbagai tanaman hortikultura dan beberapa tanaman pangan di Indonesia. Infeksi NPA mampu menurunkan kuantitas dan kualitas panen, bahkan menyebabkan gagal panen apabila terjadi sinergisme dengan patogen lain. Penggunaan pestisida kimia sintetis untuk mengendalikan Meloidogyne spp. dan patogen lain di kalangan petani sering melebihi batas pemakaian normal. Selain menyebabkan kerusakan dan pencemaran lingkungan, penggunaan pestisida kimia sintetis dapat menyebabkan gangguan kesehatan pada petani, meninggalkan residu kimia yang berbahaya bagi konsumen, dan menurunkan jumlah mikroba dan mikro fauna yang berperan penting dalam pertanian berkelanjutan. Masalah tersebut dapat ditekan tingkat kejadiannya dengan mengurangi penggunaan pestisida kimia sintetis. Terdapat banyak pilihan cara untuk mengendalikan NPA tanpa menggunakan pestisida kimia sintetis, yaitu dengan pola tanam polikultur, memanfaatkan tanaman antagonis, teknik biofumigan, penggunaan ekstrak nabati (pestisida nabati), penggenangan sawah, aplikasi agens antagonis, dan aplikasi metabolit sekunder dari mikroba. Cara-cara tersebut diketahui efektif menekan populasi NPA pada berbagai skala percobaan, dan tidak menimbulkan masalah lingkungan. Beberapa teknik aplikasi seperti pola tanam polikultur, dan aplikasi agens antagonis diketahui tidak hanya menekan populasi NPA dan mengurangi kerusakan akibat infeksi NPA, namun juga mampu meningkatkan hasil panen. Teknikteknik pengendalian patogen yang ramah lingkungan perlu dilakukan untuk mewujudkan swasembada pangan melalui pertanian berkelanjutan.
\end{abstract}

Kata kunci: Meloidogyne spp., nematoda puru akar, pengendalian

\section{LATAR BELAKANG}

Sistem pertanian konvensional mampu memberikan hasil produksi yang tinggi, namun juga terbukti menimbulkan kerusakan lingkungan yang besar. Faktor-faktor pembatas produksi hampir selalu diatasi secara instan menggunakan bahan kimia. Keberhasilan sistem pertanian konvensional hanya bersifat sementara, karena suatu saat 
kerusakan ekosistem yang disebabkan oleh sistem ini akan menjadi faktor pembatas produksi yang sangat sulit untuk diatasi [1].

Ciri khas dari sistem pertanian konvensional adalah keseragaman genetik tanaman dalam skala luas sehingga diperoleh hasil panen yang seragam dalam waktu hampir bersamaan, sehingga akan merusak keseimbangan ekosistem, dan berpotensi besar menimbulkan epidemi penyakit tanaman [1-3]. Kerusakan ekosistem berdampak besar terhadap kuantitas dan kualitas produk pertanian, sehingga saat ini berbagai cara dilakukan agar produk pertanian tetap memiliki kuantitas dan kualitas yang baik meskipun kegiatan pertanian dilakukan pada lingkungan dengan ekosistem yang sudah rusak. Berbagai intervensi dilakukan untuk mencapai tujuan tersebut, seperti penggunaan bakterisida, nematisida, fungisida, pestisida, akarisida, algasida, herbisida, maupun pupuk kimia sintetis. Berkurangnya materi organik, tanah menjadi keras, porositas tanah berkurang, nilai tukar ion tanah yang semakin rendah, rendahnya daya ikat air, dan berujung pada tingkat kesuburan tanah yang sangat rendah [4-7].

Swasembada pangan dapat tercapai apabila seluruh aspek produksi pertanian dalam keadaan yang optimal dan mendukung. Salah satu kendala yang sering menjadi faktor pembatas produksi pertanian adalah infeksi patogen. Meloidogyne spp. merupakan salah satu patogen penting dalam dunia pertanian. Nematoda ini memiliki kisaran inang yang sangat luas (bersifat kosmopolit) [8]. Berbagai tanaman penting di Indonesia telah dilaporkan terinfeksi oleh nematoda ini. Laporan infeksi Meloidogyne spp. pada tanaman pangan dan hortikultura cukup mendominasi bila dibandingkan dengan laporan infeksi oleh nematoda lain. Jumlah Meloidogyne spp. per gram akar pada tanaman padi di kelurahan Situ Gede, Bubulak, dan Caringin (Kota Bogor) secara berurutan adalah 284, 954, dan 882 [9]. Berliana [10] juga melaporkan bahwa Meloidogyne spp. mampu menginfeksi tanaman Kedelai. Jayanti [11] melaporkan bahwa Meloidogyne javanica telah menginfeksi pertanaman kentang di Bandung, Jawa Barat. Infeksi tersebut menyebabkan umbi kentang menjadi berpuru. NPA juga dilaporkan telah menginfeksi tanaman ubi jalar di papua barat, sehingga menyebabkan ukuran ubi jadi kecil dan berbentuk tidak normal [12]. Selain tanaman pangan, Meloidogyne spp. juga diketahui mampu menginfeksi tanaman perkebunan seperti lada, kapas, dan kopi, juga tanaman hortikultura seperti tomat, timun, dan wortel. 
Gejala umum yang disebabkan oleh infeksi Meloidogyne spp. adalah menguningnya daun di sekitar tajuk, tanaman menjadi kerdil, pertumbuhan terhambat, layu pada siang hari meskipun air tersedia bagi tanaman. Gejala terjadi akibat terhambatnya saluran pengangkut air dan nutrisi. Selain gejala tersebut, infeksi nematoda juga menyebabkan gejala di bawah permukaan tanah, yaitu pada akar tanaman. Tanaman yang terinfeksi oleh Meloidogyne spp. menunjukkan gejala hipertropi dan hiperplasia, yaitu membengkaknya jaringan akar tanaman. Jaringan akar tanaman yang bengkak tersebut banyak dikenal sebagai puru. Puru terbentuk karena terjadi pembelahan sel dan pembesaran sel secara berlebihan pada jaringan perisikel tanaman [13].

Tanaman yang terinfeksi oleh NPA akan terganggu sistem perakarannya, bahkan pada intensitas yang tinggi dapat menyebabkan disfungsi sistem perakaran secara total. Pembentukan akar baru pada tanaman terserang hampir tidak terjadi. Infeksi NPA pada akar menyebabkan terhambatnya penyerapan air dan unsur hara ke seluruh bagian tanaman. Akar tanaman yang terinfeksi oleh NPA biasanya memiliki ukuran kecil dan pendek dan hanya memiliki sedikit akar lateral dan rambut-rambut akar, dan berpuru. Bentuk puru akibat serangan NPA berbeda, tergantung pada spesies NPA yang menginfeksi. Bentuk puru akibat infeksi Meloidogyne spp. seperti manik-manik dan cenderung lebih kecil dibandingkan dengan puru yang diakibatkan oleh spesies NPA yang lain. Akibat kerusakan pada akar tersebut menyebabkan translokasi terhambat sehingga warna daun menguning seperti gejala kekurangan hara dan mudah layu [14].

Penggunaan teknik-teknik pengendalian NPA yang ramah lingkungan sangat diperlukan dalam rangka menunjang swasembada pangan melalui pertanian berkelanjutan. Makalah ini bertujuan untuk merangkum hasil-hasil penelitian mengenai teknik pengendalian NPA yang ramah lingkungan.

\section{PEMBAHASAN}

\section{Rotasi Tanam dan Pola Tanam Polikultur}

Pengendalian NPA sangat sulit dilakukan degan teknik pergiliran tanam, karena NPA memiliki kisaran inang yang sangat luas [15]. Meskipun tidak memberikan dampak yang nyata, pergiliran tanam tetap perlu dilakukan untuk mempertahankan kesuburan tanah, menghindari efek alelopati, serta memutus siklus beberapa penyakit 
tanaman [16]. Salah satu cara yang dapat dimanfaatkan untuk mengurangi dampak dari infeksi nematoda adalah dengan menggabungkan pergiliran tanam dan pola tanam polikultur. Pola tanam polikultur diketahui mampu menekan terjadinya epidemi penyakit tanaman [17]. Sebuah survei melaporkan bahwa tanaman tomat yang ditanam secara monokultur memiliki tingkat kerusakan akar akibat infeksi NPA lebih tinggi dibandingkan dengan tanaman tomat yang ditanam secara polikultur. Tomat yang ditanam secara polikultur juga memiliki pertumbuhan yang lebih baik dibandingkan dengan tomat yang ditanam secara monokultur [18].

\section{Ekstrak Nabati}

Potensi ekstrak nabati sebagai pengendali NPA sudah banyak dilaporkan. Terdapat 2400 jenis tumbuhan yang mengandung racun yang berguna untuk mengendalikan hama pada tanaman, 147 jenis diantaranya diketahui mampu mengendalikan nematoda [19]. Penggunaan ekstrak nabati yang banyak diteliti adalah ekstrak dari tanaman Mimba (Azadirachta indica), Tagetes (Tagetes erecta), dan Jarak (R. communis). Selain ekstrak dari ketiga tanaman tersebut, ekstrak dari tanaman lain seperti srikaya, serai wangi, serai dapur, bawang dayak, dan lempuyangan gajah juga diketahui mampu mengendalikan Meloidogyne spp [20, 21]. Ekstrak etanol (100 g per $100 \mathrm{~mL}$ air) dari mimba dan tagetes efektif menurunkan populasi Meloidogyne spp [22, 23]. Bahan aktif utama yang terdapat pada eksrak mimba adalah azadirachtin, sedangkan kandungan senyawa aktif dari bungkil jarak adalah ricin, yaitu senyawa yang sangat beracun bagi nematoda [24]. Hasil uji efektifitas ekstrak bawang dayak untuk menekan populasi NPA di tanah menunjukkan bahwa penggunaan $5 \mathrm{~g}$ serbuk bawang dayak per $5 \mathrm{~kg}$ tanah adalah hasil paling efektif dan efisien. Bawang dayak diketahui mampu menekan NPA karena memiliki senyawa bioaktif seperti flavonoid, polifenol, alkaloid, steroid, tannin, saponin dan kuinon [25].

\section{Tanaman Antagonis}

Alternatif pengendalian NPA yang ramah lingkungan dapat dilakukan dengan menggunakan tanaman antagonis. Beberapa jenis tanaman diketahui menghasilkan senyawa yang bersifat antihelmintik atau nematostatik [24] yaitu jarak (Ricinus communis), wijen (Sesamum indicum), partridge pea (Cassia fasciculata), Tagetes (Tagetes erecta), Crotalaria spectabilis, Crotalaria sp., Indigolera hirsuta, Dactylis 
glomerata, kacang tunggak, tapak dara, bawang dayak, dan tithonia (Tithonia diversifolia) [25-29,41-43]. Tanaman antagonis yang relevan digunaan di Indonesia adalah jarak, tagetes, Crotalaria spectabilis, Indigolera hirsuta, Dactylis glomerata, kacang tunggak, tapak dara dan tithonia. Kedelapan tanaman tersebut mudah ditemui dan tidak memiliki nilai ekonomis yang cukup berarti bagi petani. Teknik aplikasi tanaman antagonis cukup mudah dilakukan, yaitu dengan cara melakukan rotasi tanam dengan tanaman antagonis selama 1 musim tanam, atau dapat juga hanya 40 hari tergantung pada tingkat infeksi nematoda pada lahan tersebut.

Senyawa ricin diketahui terdapat dalam bungkil jarak. Senyawa ini mampu membunuh beberapa spesies nematoda seperti Trichodorus christiei, Xiphinema americanum, Helicotylenchus erithrinae, Globodera rostochiensis, Heterodera schachtii, Hoplolaimus indicus, M. incognita, M. arenaria, dan M. javanica [30-34]. Tanaman tagetes dan tithonia merupakan tanaman dari famili Asteraceae yang mengandung senyawa terpenoid yang berperan sebagai zat pengusir [35].

\section{Biofumigan}

Biofumigan biasa digunakan sebagai pengendali hama, patogen, dan gulma yang ada di dalam tanah. Biofumigan yang merupakan senyawa volatil bersifat toksik bagi beberapa OPT tersebut. Senyawa volatil dihasilkan oleh beberapa jenis tanaman dari famili Cruciferae (kubis-kubisan). Sebagian besar tanaman dari famili Cruciferae menghasilkan senyawa glucosinolate (GSL). Dalam proses hidrolisis GSL akan menghasilkan isotiosianit (ITS) yang mampu berperan sebagai nematisida [36, 37]. Senyawa ITS merupakan senyawa alelokimia yang sangat toksik yang dapat mematikan nematoda dengan cara menghambat pernafasan nematoda. Nematoda bernafas dengan sistem difusi, sehingga pada saat proses difusi ITS akan masuk bersama dengan pernafasan nematoda dan membunuh nematoda [38, 39].

Sisa tanaman lobak dan kubis diketahui paling efektif menekan populasi NPA di tanah. Efektifitas kedua limbah tersebut setara dengan nematisida sintetik (Furadan 3G) [38]. Aplikasi limbah tanaman lobak juga diketahui mampu menekan jumlah puru akar sebesar 60,6\% dan meningkatkan bobot daun dan batang seledri sebesar 41,9\% [36]. Aplikasi dilakukan dengan cara memotong kecil-kecil limbah Cruciferae $\left( \pm 1 \mathrm{~cm}^{2}\right)$ lalu limbah yang telah dicacah dibenamkan di dalam bedengan tanah dan ditutup dengan 
mulsa. Aplikasi limbah Cruciferae yang disarankan adalah $0,5 \mathrm{~kg}$ limbah per $5 \mathrm{~kg}$ tanah dengan masa inkubasi 1 minggu [40].

\section{Penggenangan dan Pemberoan lahan}

Penggenangan lahan dapat menyebabkan kekurangan oksigen dalam tanah. Kekurangan oksigen akan menyebabkan penurunan aktivitas, reproduksi dan penetasan telur nematoda sehingga jumlah nematoda dalam tanah menurun [44]. Semakin lama penggenangan maka jumlah nematoda dalam tanah juga semakin sedikit.

Teknik pemberoan akan efektif jika diaplikasikan di daerah yang panas maupun daerah dingin dengan curah hujan yang tinggi [45]. Temperatur tinggi melalui teknik solarisasi akan dapat membunuh nematoda. Pada dasarnya nematoda parasit dapat mati pada suhu $\pm 45^{\circ} \mathrm{C}$. Pada kedalaman $10-20 \mathrm{~cm}$ suhu tanah akan mencapai $60^{\circ} \mathrm{C}$ dan $56^{\circ} \mathrm{C}$ [54]. Sterilisasi tanah dapat dilakukan dengan cara pemberian uap panas yang dialirkan melalui pipa-pipa. Cara ini dilakukan pada tanah sebelum disebari biji/benih. Kemudian diperlukan pula perendaman bahan tanaman ke dalam air panas guna mematikan nematoda endoparasit yang menyerang akar atau pada biji tomat sebelum ditebar, suhu yang digunakan antara $50-55^{\circ} \mathrm{C}$, selama \pm 15 menit [46]

\section{Agens Hayati}

Beberapa organisme musuh alami yang efektif terhadap pengendalian nematoda di lapangan masih terbatas untuk diaplikasikan oleh petani. Misalnya Nematophthora gynophila yang mampu memarasit nematoda dengan mekanisme menurunkan populasi nematoda betina masih terbatas inangnya. Oleh karena itu perlu penelitian lebih mendalam untuk mengeksplorasi inang Nematophthora gynophila agar dapat digunakan sebagai agens hayati. Selain itu penggunaan mikoriza endofit, Verticillium chlamydosporae, Paecilomyces lilacinus, Pasteuria spp. Hirsutella spp., Trichoderma harzianum, T. viride, T. koningii bersifat toksik dan mampu menekan penetasan telur Meloidogyne spp., rizobakteri seperti Pseudomonas fluorescens, Bacillus subtilis dan cendawan endofit dapat mengurangi invasi dan perkembangan nematoda Meloidogyne spp.[47-50].

Agens hayati yang efektif untuk diaplikasikan di yaitu dengan menggunakan $T$. harzianum, selain memiliki kemampuan untuk menekan penetasan telur nematoda 
hingga $47 \%$ dan menjerat nematoda dengan hifa, agens hayati ini juga melimpah di alam. Cara aplikasi agens hayati ini yaitu dengan membuat filtrat biakan dengan media cair untuk kemudian disiramkan pada tanaman [50].

\section{Metabolit Sekunder}

Metabolit sekunder dapat dihasilkan oleh tanaman maupun agens hayati. Metabolit sekunder seperti rotenon dapat dihasilkan oleh tumbuhan tuba. Senyawa ini merupakan racun perut dan kontak untuk nematoda dan relatif aman bagi kesehatan manusia [52]. Senyawa metabolit sekunder lain yang dapat digunakan yaitu alkaloid dan tanin. Senyawa alkaloid bersifat toksin dan dapat menghambat laju metabolisme di dalam tubuh nematoda. Sedangkan senyawa tanin dapat melarutkan protein dalam kulit telur nematoda sehingga menyebabkan gagalnya penetasan telur. Tanin juga dapat menghambat sistem enzimatik nematoda dan bereaksi dengan protein penyusun sel-sel sehingga dapat mengurangi kemampuan nematoda dalam menginfeksi akar [8, 53].

P.fluorescens memproduksi antibiotik seperti 2,4-diacetylpholoroglucinol (PHL), pyoluteorin (PLT), pyrrolnitrin dan phenazine-1-carboxylate (Thomashow dan Weller, 1995). Beberapa penelitian melaporkan bahwa kelompok Bacillus dapat menghasilkan nematisida volatil dan utamanya ditandai dengan benzene acetaldehyde, 2-nonanone, decanal, 2- undecanone dan dimethil disulphide [56]. Selain itu, senyawa etil asetat yang dihasilkan oleh Paecilomyces lilacinus dan Pseudomonas aeruginosa juga efektif untuk menekan juvenil Meloidogyne spp.[57]

\section{DAFTAR PUSTAKA}

[1] Aryantha INP. 2002. Membangun sistim pertanian berkelanjutan. Diskusi sehari dalam upaya mengurangi penggunaan pupuk, Menristek-BPPT. p. 1-13.

[2] Gibson R, Pearce S, Morris R, Symondson W, Memmott J. 2007. Plant diversity and land use under organic and conventional agriculture: a whole-farm approach. Journal of Applied Ecology;44:792-803.

[3] Shipton P. 1977. Monoculture and soilborne plant pathogens. Annual Review of Phytopathology; 15:387-407.

[4] Abawi G, Widmer T. 2000. Impact of soil health management practices on soilborne pathogens, nematodes and root diseases of vegetable crops. Applied Soil Ecology;15:37-47. 
[5] Singh H, Singh K. 1993. Effect of residue placement and chemical fertilizer on soil microbial biomass under tropical dryland cultivation. Biology and Fertility of Soils; $16: 275-81$.

[6] Stoate C, Boatman N, Borralho R, Carvalho CR, De Snoo G, Eden P. 2001. Ecological impacts of arable intensification in Europe. Journal of environmental management; 63:337-65.

[7] Yan D, Wang D, Yang L. 2007. Long-term effect of chemical fertilizer, straw, and manure on labile organic matter fractions in a paddy soil. Biology and Fertility of Soils;44:93-101.

[8] Dropkin, V. 1996. Pengantar Nematologi Tumbuhan. Terjemahan oleh Supratoyo: Gadjah Mada University Press. Yogyakarta.

[9] Febriyani, D. 2003. Nematoda Penyebab Puru Akar (Meloidogyne spp.) Pada Tanaman Padi Sawah Di Kelurahan Situ Gede, Bubulak, Kecamatan Bogor Barat Dan Desa Caringin, Kecamatan Dramaga, Bogor [Skripsi]. Bogor (ID): Institut Pertanian Bogor.

[10] Berliana, EC. 2010. Potensi nematoda entomopatogen untuk pengendalian nematoda puru akar (Meloidogyne spp.) pada tanaman kedelai [Skripsi]. Bogor (ID): Institut Pertanian Bogor.

[11] Jayanti, W. 2011. Identifikasi spesies nematoda puru akar (Meloidogyne spp.) pada umbi kentang asal Pangalengan dan Kertasari, Kabupaten Bandung, Jawa Barat [Skripsi]. Bogor (ID): Institut Pertanian Bogor.

[12] Tuminem, Supramana, Sinaga MS, Giyanto. 2015. First Report on the Root Knot Nematodes Meloidogyne spp. of Sweetpotatoes in Sorong Regency, West PapuaIndonesia.;21:325-34.

[13] Agrios, G. 2005. Plant diseases caused by nematodes. Plant pathology. p. 565-97.

[14] Davis RM, Raid RN. 2002. Compendium of umbelliferous crop diseases: American Phytopathological Society (APS Press)

[15] Rodriguez-Kabana, R, Canullo, G.H. 1992. Cropping systems for the management of phytonematodes. Phytoparasitica;20:211-24.

[16] Harni, R. dan Mustika, I. 2002. Pengendalian Nematoda parasit tanaman lada berwawasan lingkungan. Perkembangan Teknologi Tanaman Rempah dan Obat; $14: 1$.

[17] Madden LV, Hughes G, Van den Bosch F. 2007. The study of plant disease epidemics: American Phytopathological Society St. Paul

[18] Pradana, A.P, Putri, D, Munif, A. 2014. Analisis Populasi Nematoda Parasit Pada Lahan Tanaman Tomat Dengan Sistem Tanam Monokultur Dan Polikultur. Seminar Nasional Pengendalian Penyakit pada Tanaman Pertanian Ramah Lingkungan: Universitas Gadjah Mada; p. 147-55.

[19] Grainge, M dan Ahmed, S. 1988. Handbook of plants with pest-control properties: John Wiley \& Sons Limited.

[20] Brown, R.H. dan Kerry, BR. 1987. Principles and practice of nematode control in crops: Academic Press Australia.

[21] Jairajpuri, M.S, Alam, M,M, Ahmad, I. 1990. Nematode bio-control (aspects and prospects). Nematode bio-control (aspects and prospects)

[22] Agbenin, N., Emechebe, A., Marley, P., Akpa, A. 2005. Evaluation of nematicidal action of some botanicals on Meloidogyne incognita in vivo and in vitro. Journal of Agriculture and Rural Development in the Tropics and Subtropics (JARTS);106:29-39. 
[23] Khan, A., Sayed, M., Shaukat, S., Handoo, Z. 2008. Efficacy of four plant extracts on nematodes associated with papaya in Sindh, Pakistan. Nematol Medit;36:93-8.

[24] Gommers, F.J. 1973. Nematicidal principles in Compositae. Mededelingen Landbouwhogeschool Wageningen;73.

[25] Elly, L., Edwin, N.F., Dewi, F. 2013 Kemampuan serbuk bawang dayak menekan serangan Meloidogyne spp. Pada tomât. Agroscientiae;20:53-5.

[26] Mustika, I. dan Nuryani, Y. 2006. Strategi pengendalian nematoda parasit pada tanaman nilam. Jurnal Penelitian dan Pengembangan Pertanian;25:7-15.

[27] Odeyemi, I. dan Adewale, K. 2011. Phythonematoxic properties and nematicidal potential of Tithonia diversifolia extract and residue on Meloidogyne incognita infecting yam (Discoria rotundata). Archives of Phytopathology and plant protection;44:1745-53.

[28] Tsay, T., Wu, S., Lin, Y. 2004. Evaluation of Asteraceae plants for control of Meloidogyne incognita. Journal of Nematology;36:36.

[29] Yang, X-j., He, Y-X., Lu, X-s., Chen, Q-h. 2005. Determining for nematicidal activity of some plant crude extracts against the second juvenile of Meloidogyne spp.[J]. Fujian Journal of Agricultural Sciences;1:005.

[30] Adegbite, A. dan Adesiyan, S. 2005. Root extracts of plants to control root-knot nematode on edible soybean. World Journal of Agricultural Sciences;1:18-21.

[31] Akhtar, M. dan Malik, A. 2000. Roles of organic soil amendments and soil organisms in the biological control of plant-parasitic nematodes: a review. Bioresource Technology;74:35-47.

[32] McSorley, R.. 1999 Host suitability of potential cover crops for root-knot nematodes. Journal of nematology;31:619.

[33] Rich, J., Rahi, G., Opperman, C., Davis, E. 1989. Research Notes: Influence of the Castor Bean (Ricinus communis) Lectin (Ricin) on Motility of Meloidogyne incognita. Nematropica; 19:99-103.

[34] Zaki, F. dan Bhatti, D. 1990. Effect of castor (Ricinus communis) and the biocontrol fungus Paecilomyces lilacinus on Meloidogyne Ja Vanica. Nematologica;36:114-22.

[35] Villarreal, M.L., Alvarez, L., Alonso, D., Navarro, V., Garcia. P., Delgado, G. 1994. Cytotoxic and antimicrobial screening of selected terpenoids from Asteraceae species. Journal of ethnopharmacology;42:25-9.

[36] Anita, B. 2012. Crucifer vegetable leaf wastes as biofumigants for the management of root knot nematode (Meloidogyne hapla Chitwood) in celery (Apium graveolens L.). Journal of Biopesticides;5.

[37] Monfort, W., Csinos, A., Desaeger, J., Seebold, K., Webster, T., Diaz-Perez, J. 2007. Evaluating Brassica species as an alternative control measure for root-knot nematode $(M$. incognita $)$ in Georgia vegetable plasticulture. Crop Protection;26:1359-68.

[38] Daulay, N.S. 2013. Sisa Tanaman Cruciferae Sebagai Biofumigan Untuk Mengendalikan Nematoda Puru Akar (Meloidogyne spp.) [Skripsi]. Bogor (ID): Institut Pertanian Bogor.

[39] Gimsing, A.L. dan Kirkegaard, J. 2006. Glucosinolate and isothiocyanate concentration in soil following incorporation of Brassica biofumigants. Soil Biology and Biochemistry;38:2255-64. 
[40] Rosya, A. 2015. Keefektifan Limbah Brassica Sebagai Biofumigan Dalam Pengendalian Nematoda Puru Akar (Meloidogyne Spp.) Pada Tanaman Tomat [Thesis]. Bogor (ID): Institut Pertanian Bogor.

[41] Christie, J.R. 1959. Plant nematodes, their bionomics and control. Gainesville, Florida, USA, Florida Agricultural Experiment Station.

[42] Godfrey, G.H. \& Hagan, H.R. 1934. A study of the root-knot nematode trap crop under field soil conditions. Phytopatholgy, 24: 648-658.

[43] Patel, H.R., Patel, DJ., Patel, C.C. \& Thakar, N.A. 1991. Management of rootknot nematodes by Periwinkle. Nematol. Medit., 19: 65-66.

[44] Taylor, A.L. and J.N. Sasser. 1978. Biologi, identification and control of root knot nematodes (Meloidogyne spp) International Carolina Meloidogyne Project. Printed by Nor Carolina State University Graphics. 107 page.

[45] Trivedi, P.C. \& Barker, K.R. 1986. Management of nematodes by cultural practices. Nematropica, 16: 213-236.

[46] Elmore, C. L., Stapleton, J. J., Bell, C. E. and DeVay, J. E. 1997. Soil Solarization: A nonpesticidal method for controlling diseases, nematodes and weeds. Univ.Calif. Agric. Nat. Res, Oakland.

[47] Stirling, G.R. 1991. Biological control of plant-parasitic nematodes. Wallingford, UK, CAB International. $282 \mathrm{pp}$.

[48] Sikora, R.A. 1992. Management of the antagonistic potential in agricultural ecosystems for the biological control of plant parasitic nematodes. Annual Review of Phytopathology

[49] Yus, I.D.M, Raharjo, B.T., Himawan, T. 2014. Pengaruh aplikasi bakteri Pseudomonas fluorescens dan Bacillus subtilis terhadap mortalitas nematoda puru akar (Meloidogyne javanica) di laboratorium. Jurnal HPT Vol. 2 No. 3

[50] Santoso, A., Himawan, T., Tarno, H. 2014. Pengaruh filtrat biakan Trichoderma spp. terhadap penetasan telur nematoda puru akar (Meloidogyne sp.). Jurnal HPT Vol. 2 No. 4

[51] Jaya, I.B.M.D, Sritamin, M., Puspawati, N.M. 2014. Uji Efektifitas Ekstrak Daun dari Beberapa Jenis Tanaman untuk Mengendalikan Nematoda Puru Akar Meloidogyne Spp. pada Tanaman Cabai (Capsicum Annum L). E-Jurnal Agroekoteknologi Tropika Vol. 3 No.2

[52] Kardinan, A. 2001. Pestisida Nabati, Ramuan dan Aplikasi. PT.Penebar Swadaya.

[53] Lopez. 2005. In vitro effect of condosed tannins from tropical fodder crops againts eggs and larvae of the nematode Haemunchus contortus. Journal of Food, Agriculture and Environment (2): 191-194.

[54] Thomashow, L. S. and D. M. Weller. 1995. Current Concepts in the Use of Introduced Bacteria for Biological Disease Control. In: Stacey, G., Keen, N. (Eds.), Plant-microbe interactions, vol. 1. Chapman \& Hall. New York. pp. 187235.

[55] Saleh, H., Abu-Gharbieh, W.L, Al-Banna, L. 1989. Augmentation of soil solarization effects by application of solar-heated water. Nematol. Medit., 17: 127129.

[56] Lindberg, G. S. 1981. An Antibiotic Lethal to Fungi. Plant Disease 65: 680-683.

[57] Siddiqui, I. A., Qureshi, S. A., Sultana, V., Ehteshamul-Haque, S. and Gaffar, A., 2000. Biological control of root rot - root knot disease complex of tomato. Plant and Soil; 227: 163-169. 